\title{
Influence of size of onion bulb cv. 'Czerniakowska' on its dormancy, sprouting and rooting
}

\section{BIELINSKA-CZARNECKA *, A. KĘPKOWA **, E. KIELAK * i E. ZDANOWSKA *}

\begin{abstract}
* University of Agriculture and Teachers Callege, Prusa 12, 08-110 Siedlce, Poland
** Research Institute of Vegetable Crops, 22 Lipca, 96-100 Skierniewice, Poland
\end{abstract}

(Received: December 1, 1979)

\begin{abstract}
Sprouting and rooting of onion bulb explants (bulbs deprived of open and closed shells) and of whole onion bulbs of three sizes, horizontal diameters: 2.5-3.5 cm, 3.6-5.0 cm, $5.1-7 \mathrm{~cm}$ were studied. During storage the earliest sprouting and rooting of bulb explants and of the whole onion bulbs was observed in small bulbs of diameters: 2.5-3.5, and the latest in large bulbs of 5.1-7.0 cm. The longer the period of storage the larger the amount of sprouted and rooted bulb explants and whole bulbs. At the same time differences in the rate of sprouting and rooting in small and large onion bulbs were diminishing. In bulb explants, sprouting and rooting appeared much earlier and in a larger number than in whole onion bulbs. However, bulb explants of large bulbs generally had more leaves than those of small onion bulbs.
\end{abstract}

\section{INTRODUCTION}

Storage of onion bulbs depends, to a large extent on their rate of sprouting and rooting. Chroboczek (1936) has already indicated possible dependence of the extent of storage life of onion bulbs on their size. However, investigations carried out under his guidance by S n a g le w sk a (1936) did not give any definite results.

Later experiments (1956-1964), undertaken by $\mathrm{Keq \textrm {pow }}$ a and $\mathrm{Umi}$ i cka (1970) revealed worse storage results in onion bulbs of a smaller diameter (3.5-4.5) than of large ones $(4.5-7 \mathrm{~cm})$.

In earlier experiments, $\mathrm{K}$ e $\mathrm{pk}$ ow a (1963) also observed faster sprouting in the initial stage of storage of smaller onion bulbs. In the present experiment, studies on sprouting and rooting in onion bulbs of three sizes, cv. 'Czerniakowska' were carried out. The observations were made on, both whole bulbs as well as on bulbs explants deprived of open and closed shells. 


\section{METHODS AND MATERIALS}

Experiments were carried out in the years 1977-78. Onion bulbs were taken from Vegetable Experimental Station, Guzów. Onion bulbs collected in the field were then delivered to the Institute of Vegetable Crops in Skierniewice where onion leaves were excised and the bulbs put in a cold storage in the temperature $0-2^{\circ} \mathrm{C}$. Each month, since October till April 1978, onion bulbs were delivered to the Department of Plant Physiology of the University of Agriculture and Teachers College, Siedlce for the purpose of experiments. In experiments, onion bulbs of theer sizes of horizontal diameters: a) $2-5-3.5$, b) $3.6-5.0 \mathrm{~cm}$, c) $5.1-7.0 \mathrm{~cm}$ were used. Each time, total number of planted onion bulbs reached a hundred, which included 50 whole onion bulbs and 50 bulb explants. The experiment was repeated twice. Thick, open and closed shells were taken off whole bulbs before planting their explants. The number of shells depended on bulb size (Table 1). Before planting bulb explants,

Table 1

$$
\begin{gathered}
\text { Average number of thick shells } \\
\text { (open and closed) taken off one } \\
\text { onion bulb }
\end{gathered}
$$

\begin{tabular}{ccc}
\hline $\begin{array}{l}\text { Bulb horizontal } \\
\text { diameter in cm }\end{array}$ & \multicolumn{2}{c}{ Number of shells } \\
\cline { 2 - 3 } open & closed \\
\hline $2.5-3.5$ & 1.0 & $2.6-2.9$ \\
\hline $3.6-5.0$ & $1.6-1.9$ & $3.2-3.6$ \\
\hline $5.1-7.0$ & $2.0-2.2$ & $4.0-4.6$
\end{tabular}

the longth of sheel (being $0.5 \mathrm{~cm}$ for all bulb sizes) and of meristem and young leaves (Table 2) were measured. The length of meristem and

Table 2

Average length of bulb explants in $\mathrm{cm}$

\begin{tabular}{ccccccc}
\hline Bulb & \multicolumn{5}{c}{ Months of planting } \\
\cline { 2 - 8 } $\begin{array}{c}\text { horizontal } \\
\text { diameter } \\
\text { in cm }\end{array}$ & $\begin{array}{c}\text { Octo- } \\
\text { ber }\end{array}$ & $\begin{array}{c}\text { Novem- } \\
\text { ber }\end{array}$ & $\begin{array}{c}\text { Decem- } \\
\text { ber }\end{array}$ & $\begin{array}{c}\text { Janu- } \\
\text { ary }\end{array}$ & $\begin{array}{c}\text { Febru- } \\
\text { ary }\end{array}$ & April \\
\hline $2.5-3.5$ & 1.4 & 1.5 & 1.8 & 2.2 & 2.9 & 3.5 \\
\hline $3.6-5.0$ & 2.0 & 2.9 & 2.5 & 2.9 & 2.9 & 3.7 \\
\hline $5.1-7.0$ & 2.8 & 3.1 & 3.2 & 3.4 & 3.6 & 3.7
\end{tabular}


young leaves increased with the time of storage. At the same time considerable differences in the length of meristem and young leaves observed at the begining of storage were disappearing.

Whole bulbs and bulb explants were planted in growing dishes filled with styrofoam daily damped by equal amount of water. Continuous fluorescent ligth was used during the whole experiment. Observations were made 5 and 10 days after the date of planting. After 5 days, the number of sprouting bulb explants was recorded (in whole bulbs no sprouting was observed).

After 10 days the following observations were recorded:

number of sprouted explants and whole bulbs,

number of leaves in bulb explants and in whole onion bulbs,

length of the longest leave in explants and in whole onion bulbs, number of roots in bulb explants and whole onion bulbs,

length of the longest root in bulb explants and whole onion bulbs, Data presented in tables are the average of two repetitions.

\section{RESUL.TS}

Explants from bulbs of all sizes began sprouting after the period of 5 days. However, distinct differences in the number of bulb meristems sprouted and young leaves which appeared depended on the size of bulb. The largest number of sprouted bulb explants was observed in onion bulbs of diameter: $2.5-3.5 \mathrm{~cm}$ (Table 3 ). This difference became smaller at the end of storage period.

10 days after planting, both: bulb explants and whole onion bulbs were sprouting. Bulb explants of all onion sizes sprouted much earlier and in greater number than whole bulbs (Table 3). The rate of growth was the highest in explants and whole bulbs of diameters $2.5-3.5 \mathrm{~cm}$. However, while differences in a number of sprouted bulb explants disappeared at the end of storage period they remained unchanged and very distinct in whole onion bulbs of various diameters. During total storage time the largest number of leaves was observed in bulb explants of diameter 5.1-7.0 cm, the smallest number in bulb explants of diameter 2.5-3.5 (Table 4). In whole small bulbs sprouting appeared earlier than in larger bulbs. Eince the moment of cutting through thick onion leaves covering bulb explant the number of leaves in whole bulbs of a large diameter was bigger than in small bulbs.

In whole bulbs, the length of the longest leaves (Table 5) was bigger than in bulb explants since the moment of cutting through thick shells. In large bulbs a correlation between the size of a bulb and the length of longest leaves was of a positive character. This trend however, in bulb explants was not as strong and frequent. Bulb rooting both, in bulb 
Average number of sprouted (of the total 25 in each repetition) bulb explants

\begin{tabular}{|c|c|c|c|c|c|}
\hline \multirow{5}{*}{$\begin{array}{l}\text { Bulb horizontal } \\
\text { diameter } \\
\text { in } \mathrm{cm}\end{array}$} & \multicolumn{5}{|r|}{ Months of } \\
\hline & October & \multicolumn{3}{|c|}{ November } & December \\
\hline & bulb explants & whole & bulb explants & whole & bulb explants \\
\hline & $\begin{array}{c}\text { after after } \\
5 \text { days } 10 \text { days }\end{array}$ & $\begin{array}{l}\text { bulbs } \\
\text { after }\end{array}$ & $\begin{array}{l}\text { after after } \\
5 \text { days } 10 \text { days }\end{array}$ & $\begin{array}{l}\text { bulbs } \\
\text { after }\end{array}$ & $\begin{array}{l}\text { after after } \\
5 \text { days } 10 \text { days }\end{array}$ \\
\hline & & 10 days & & 10 days & \\
\hline
\end{tabular}

\begin{tabular}{rrrrrrrrr}
$2.5-3.5$ & 16.5 & 20.5 & 0.0 & 18.0 & 20.5 & 1.0 & 18.5 & 22.0 \\
\hline $3.6-5.0$ & 12.5 & 15.5 & 0.0 & 16.0 & 19.0 & 0.0 & 17.0 & 20.5 \\
\hline $5.1-7.0$ & 10.5 & 10.5 & 0.0 & 13.0 & 16.5 & 0.0 & 15.5 & 18.5 \\
\hline
\end{tabular}

explants and whole bulbs appeared to be the fastest in bulbs of diameter 2.5-3.5 cm (Table 6). In bulb explants the increase in roots was, until the final stage, the strongest in explants of diameters $2.5-3.5 \mathrm{~cm}$, while in whole onion bulbs the number of roots, since their appearance, was increasing with the size of bulb diameter.

The biggest length of the longest root was found in bulb explants of diameter 2.5-3.5 cm (Table 7).

In whole bulbs, bulbs of diameter $2.5-3.5 \mathrm{~cm}$ undergone rooting earlier and initially faster (Table 7). Later on, the increase in roots in large bulbs was faster and in spring time (April) the biggest length of the longest root was noticed in bulbs of diameter $5.1-7.0 \mathrm{~cm}$.

\section{DISCUSSION}

Results obtained in this experiment confirm earlier observations of Kępkowa (1963), Kępkowa and Umięcka (1970) and in the second year of experiment those of $\mathrm{S} \mathrm{nag} \mathrm{lew} \mathrm{ska} \mathrm{(1936).}$

Studies on bulb sprouting and rooting in whole onions of three sizes and in bulb explants made it possible to eliminate, to large extent the influence of various numbers of thick shells containing storage substances on the process mentioned above (thought slight differences in the amount of storage substances depending on the size of bulb explants still existed). Although the procedure of shells excision causes changes in the activity of endogenous growth regulators (the so called "wounding effect") (Abdel-Rahman and Isenberg, 1973) it can be assumed that these changes in all onion bulbs of all sizes follow the same direction.

In the case of both, whole onion bulbs and bulb explants, it was 
after 5 and 10 days and of whole bulbs 10 days after planting

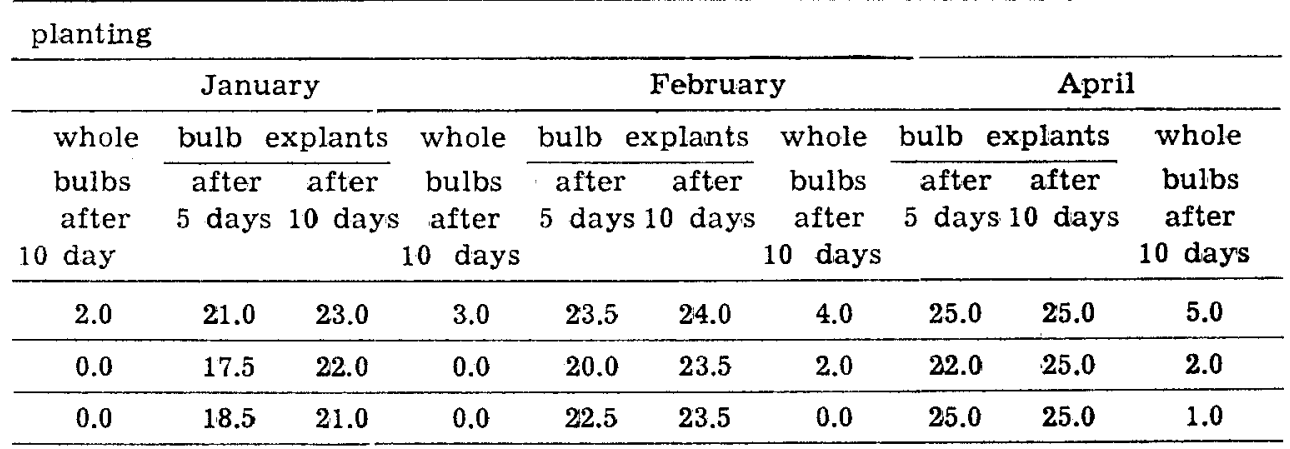

found that sprouting and rooting was slower, the bigger was bulb diameter.

In the case of whole large bulbs, their later sprouting could be caused by the necessity of overcoming an obstacle, i.e. cutting through more numerous shells. When this mechanical obstacle is absent as it is in the case of bulb explants deprived of shells, the explants originating from small bulbs also sprouted and rooted faster. This observation points to a possibly hormonal source of this phenomenon and to a less deep dormancy in small bulbs than in large ones in the same storage period. The above may result from earlier drying in the field and earlier onest of dormancy in small bulbs, and in consequence in earlier ending of dormancy.

Differences in rates of sprouting in bulb explants of various diameters decreased with the time, while differences in rates of rooting in bulb explants between the largest and smallest onion bulbs remained the same until the end of experiment. This suggest different mechanisms of the two processes. Determination of activity of hormons belonging to various groups, presumably active at the end of dormancy period could probably explain to some extent, these phenomena. It seems however, that a greater amount of nutrients in large bulbs (and also, to same degree, in originating from them explants) seems to play the main role in the number of leaves sprouting from each bulb (or bulb explant) and in the length of the longest leaves and the longest root. In whole bulbs this factor is considered to be also decissive as to the number of roots.

To sum up the discussion, it may be stated that small bulbs are of less deep dormancy and faster sprouting and rooting.

When the dormancy is over, farther growth is more intensive in large onion bulbs containing more nutrients. 


\section{Table 4}

Average number of leaves in bulb explants and whole bulbs 10 days after the date of planting

\begin{tabular}{|c|c|c|c|c|c|c|c|c|c|c|c|c|}
\hline \multirow{3}{*}{$\begin{array}{l}\text { Bulb horizontal } \\
\text { diameter } \\
\text { in } \mathrm{cm}\end{array}$} & \multicolumn{10}{|c|}{ Monthis of planting } & & \\
\hline & \multicolumn{2}{|c|}{ October } & \multicolumn{2}{|c|}{ November } & \multicolumn{2}{|c|}{ December } & \multicolumn{2}{|c|}{ January } & \multicolumn{2}{|c|}{ February } & \multicolumn{2}{|c|}{ April } \\
\hline & $\begin{array}{c}\text { bulb } \\
\text { explants }\end{array}$ & $\begin{array}{l}\text { whole } \\
\text { bulbs }\end{array}$ & $\begin{array}{c}\text { bulb } \\
\text { explants }\end{array}$ & $\begin{array}{l}\text { whole } \\
\text { bulbs }\end{array}$ & $\begin{array}{c}\text { bulb } \\
\text { explants }\end{array}$ & $\begin{array}{c}\text { whole } \\
\text { bulbs }\end{array}$ & $\begin{array}{c}\text { bulb } \\
\text { explants }\end{array}$ & $\begin{array}{l}\text { whole } \\
\text { bulbs }\end{array}$ & $\begin{array}{c}\text { bulb } \\
\text { explants }\end{array}$ & $\begin{array}{l}\text { whole } \\
\text { bulbs }\end{array}$ & $\begin{array}{c}\text { bulb } \\
\text { explants }\end{array}$ & $\begin{array}{l}\text { whole } \\
\text { bulbs }\end{array}$ \\
\hline $2.5-3.5$ & 1.6 & 0.0 & 1.7 & 3.0 & 2.8 & 3.3 & 2.1 & 3.6 & 2.2 & 3.7 & 3.2 & 6.0 \\
\hline $3.6-5.0$ & 2.0 & 0.0 & 2.1 & 0.0 & 2.4 & 0.0 & 2.6 & 0.0 & 3.8 & 4.5 & 4.4 & 4.9 \\
\hline $5.1-7.0$ & 2.3 & 0.0 & 2.8 & 0.0 & 2.8 & 0.0 & 3.5 & 0.0 & 3.9 & 0.0 & 4.8 & 7.0 \\
\hline
\end{tabular}

Table 5

Average lengths of the longest leaves in bulb explants and in whole bulbs 10 days after the date of planting in $\mathrm{cm}$

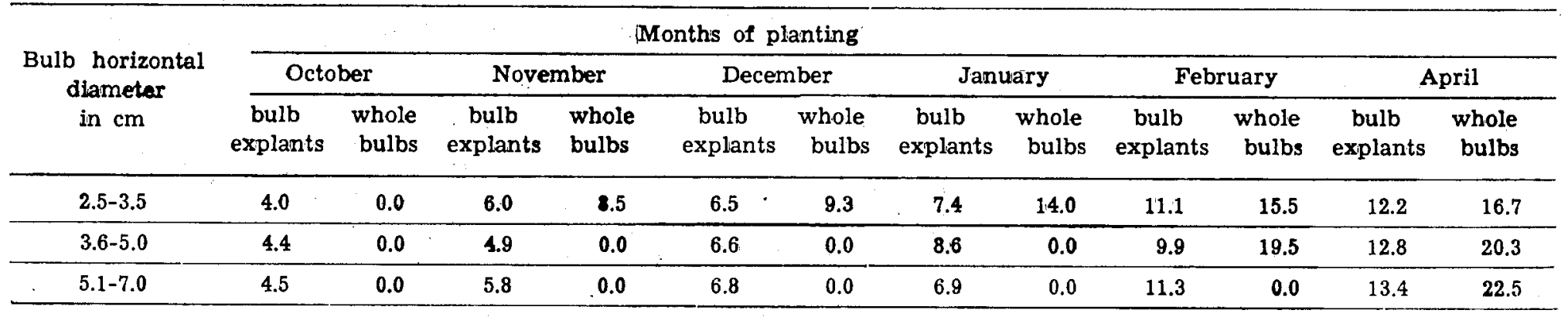


Table 6

Average number of roots in bulb explants in whole bulbs 10 days after the date of planting

\begin{tabular}{|c|c|c|c|c|c|c|c|c|c|c|c|c|}
\hline \multirow{3}{*}{$\begin{array}{l}\text { Bulb horizontal } \\
\text { diameter } \\
\text { in } \mathrm{cm}\end{array}$} & \multicolumn{12}{|c|}{ Months of planting } \\
\hline & \multicolumn{2}{|c|}{ October } & \multicolumn{2}{|c|}{ November } & \multicolumn{2}{|c|}{ December } & \multicolumn{2}{|c|}{ January } & \multicolumn{2}{|c|}{ February } & \multicolumn{2}{|c|}{ April } \\
\hline & $\begin{array}{c}\text { bulb } \\
\text { explants }\end{array}$ & $\begin{array}{l}\text { whole } \\
\text { bulbs }\end{array}$ & $\begin{array}{c}\text { bulb } \\
\text { explants }\end{array}$ & $\begin{array}{l}\text { whole } \\
\text { bulbs }\end{array}$ & $\begin{array}{c}\text { bulb } \\
\text { explants }\end{array}$ & $\begin{array}{c}\text { whole } \\
\text { bulbs }\end{array}$ & $\begin{array}{l}\text { bulb } \\
\text { explants }\end{array}$ & $\begin{array}{c}\text { whole } \\
\text { bulbs }\end{array}$ & $\begin{array}{l}\text { bulb } \\
\text { explants }\end{array}$ & $\begin{array}{c}\text { whole } \\
\text { bulbs }\end{array}$ & $\begin{array}{c}\text { bulb } \\
\text { explants }\end{array}$ & $\begin{array}{l}\text { whole } \\
\text { bulbs }\end{array}$ \\
\hline 2.5-3.5 & 12.5 & 0.0 & 13.5 & 10.0 & 14.5 & 12.5 & 19.7 & 15.0 & 20.7 & 15.3 & 22.2 & 17.2 \\
\hline $3.6-5.0$ & 10.7 & 0.0 & 10.9 & 0.0 & 11.9 & 0.0 & 13.4 & 0.0 & 15.3 & 17.3 & 22.0 & 24.5 \\
\hline $5.1-7.0$ & 9.2 & 0.0 & 10.2 & 0.0 & 11.6 & 0.0 & 13.7 & 0.0 & 15.3 & 0.0 & 16.0 & 28.2 \\
\hline
\end{tabular}

Table 7

Average lengths of longest root in bulb explants and in whole bulbs 10 days after the date of planting in $\mathrm{cm}$

\begin{tabular}{|c|c|c|c|c|c|c|c|c|c|c|c|c|}
\hline \multirow{3}{*}{$\begin{array}{l}\text { Bulb horizontal } \\
\text { diameter } \\
\text { in } \mathrm{cm}\end{array}$} & \multicolumn{10}{|c|}{ Months of planting } & \\
\hline & \multicolumn{2}{|c|}{ October } & \multicolumn{2}{|c|}{ November } & \multicolumn{2}{|c|}{ December } & \multicolumn{2}{|c|}{ January } & \multicolumn{2}{|c|}{ February } & \multicolumn{2}{|c|}{ April } \\
\hline & $\begin{array}{c}\text { bulb } \\
\text { explants }\end{array}$ & $\begin{array}{l}\text { whole } \\
\text { bulbs }\end{array}$ & $\begin{array}{c}\text { bulb } \\
\text { explants }\end{array}$ & $\begin{array}{l}\text { whole } \\
\text { bulbs }\end{array}$ & $\begin{array}{c}\text { bulb } \\
\text { explants }\end{array}$ & $\begin{array}{l}\text { whole } \\
\text { bulbs }\end{array}$ & $\begin{array}{c}\text { bulb } \\
\text { explants }\end{array}$ & $\begin{array}{l}\text { whole } \\
\text { bulbs }\end{array}$ & $\begin{array}{c}\text { bulb } \\
\text { explants }\end{array}$ & $\begin{array}{l}\text { whole } \\
\text { bulbs }\end{array}$ & $\begin{array}{c}\text { bulb } \\
\text { explants }\end{array}$ & $\begin{array}{l}\text { whole } \\
\text { bulbs }\end{array}$ \\
\hline $2.5-3.5$ & 2.6 & 0.0 & 2.5 & 4.0 & 2.7 & 4.2 & 3.0 & 4.5 & 3.5 & 4.5 & 4.2 . & 4.7 \\
\hline $3.6-5.0$ & 1.2 & 0.0 & 1.7 & 0.0 & 2.6 & 0.0 & 2.8 & 0.0 & 3.1 & 4.5 & 3.1 & 4.6 \\
\hline $5.1-7.0$ & 1.7 & 0.0 & 1.8 & 0.0 & 2.1 & 0.0 & 2.4 & 0.0 & 2.9 & 0.0 & 3.2 & 5.2 \\
\hline
\end{tabular}




\section{REFERENCES}

Abde l-R a hman M., I senberg F. M. R., 1974. The role of exogenous plant regulators in the dormancy of onion bulbs. J. Agric. Sci. Camb. 82: 113-116.

Chroboczek E., 1936. Badania nad uprawą i przechowywaniem cebuli. Rocz. Nauk ogrod. 3: 58-137.

Kępkowa A., 1963. Wpływ hydrazydu maleinowego na przechowywanie cebuli. Nieopublikowana praca doktorska. Katedra Warzywnictwa SGGW, Skierniewice.

Kępkowa A., Umięcka L., 1970. Wpływ wielkości cebuli oraz ilości cebuli w opakowaniu na jej przechowywanie w różnych warunkach. Biul. warz. 11: 355-371.

Snaglewska Z., 1936. Sposoby uprawy cebuli i jej przechwywanie. Nieopublikowana praca dyplomowa. Zakład Uprawy i Hodowli Warzyw SGGW, Skierniewice.

\section{Wpływ wielkości cebuli na wychodzenie w szczypior i w korzenie cebuli odmiany 'Czerniakowska'}

\section{Streszczenie}

Badano wyrastanie w szczypior i korzenie stożków cebuli i calych cebul trzech wielkości: o $(D$ poziomej 2,5-3,5 cm; 3,6-5,0 cm; 5,1-7,0 cm. W czasie przechowywania najwcześniej wyrastały $w$ szczypior i $w$ korzenie stożki i małe cebule o $\varnothing$ 2,5-3,5 cm, a najwolniej duże $0 \phi 5,1-7,0 \mathrm{~cm}$. W miarę przedłużania się okresu przechowywania zwiększała się ilość wyrośniętych $w$ szczypior i $w$ korzenie zarówno stożków, jak i całych cebul, jednocześnie zmniejszały się różnice w szybkości wyrastania $w$ szczypior $i$ w korzenie między małymi i dużymi cebulami. Wyrastanie w szczypior i w korzenie zachodziło wcześniej i w dużo większym procencie u stożków cebuli niż u całych cebul. 